\title{
Primary breast diffuse large B-cell lymphoma in the era of rituximab
}

This article was published in the following Dove Press journal:

OncoTargets and Therapy

7 October 2016

Number of times this article has been viewed

\author{
Na Zhang* \\ Caineng Cao* \\ Yuan Zhu \\ Peng Liu \\ Luying Liu \\ Ke Lu \\ Jialin Luo \\ Ning Zhou \\ Department of Radiation Oncology, \\ Zhejiang Key Laboratory of Radiation \\ Oncology, Zhejiang Cancer Hospital, \\ Hangzhou, People's Republic of China \\ *These authors contributed equally \\ to this work
}

Background and objective: The aim of this study was to summarize the clinical characteristics and evaluate the management approaches of primary breast diffuse large B-cell lymphoma (DLBCL) in the era of rituximab.

Patients and methods: A total of 24 female patients with newly diagnosed primary breast DLBCL treated between April 2006 and May 2013 were analyzed retrospectively. Ten patients (41.7\%) received rituximab.

Results: For the whole group, the median age was 50 years (range $24-69$ years). All patients had the disease detected with a palpable mass. The estimated 5-year overall survival and progressionfree survival (PFS) rates of all the patients were $78.9 \%$ and $79.2 \%$, respectively. A nonstatistically significant increase in PFS and overall survival was observed when rituximab was administered (5-year PFS: $90 \%$ vs $71.4 \%, P=0.285$; 5 -year overall survival: $90 \%$ vs $71.4 \%, P=0.239$ ).

Conclusion: Primary breast DLBCL appears to be a rare disease. Adding rituximab might improve survival in patients with primary breast DLBCL. Further prospective studies are needed to evaluate the role of rituximab for primary breast DLBCL.

Keywords: primary breast lymphoma, diffuse large B-cell lymphoma, rituximab, prognosis

\section{Introduction}

Primary breast lymphoma (PBL) was first described in $1959 .{ }^{1}$ It represents $\sim 1 \%$ of all non-Hodgkin lymphoma (NHL), and the most predominant subtype is diffuse large B-cell lymphoma (DLBCL). Additionally, a tendency for central nervous system (CNS) progression and a significant risk of contralateral breast involvement have been identified..$^{2-9}$

Optimal treatment strategies for primary breast DLBCL have remained undefined; to date, only two prospective trials have been reported. The first trial included 96 patients who were randomized to chemotherapy, radiation therapy, or both in the prerituximab era. ${ }^{8}$ The results of the first trial indicated that chemotherapy combined with radiation therapy was the best treatment with improvement in event-free survival and overall survival (OS). The second was a single-arm trial utilizing a dose-dense regimen (CEOP-14) and rituximab in 32 patients. ${ }^{10}$ The complete response rate, event free-survival, and OS were similar to those of historical controls. The purpose of this retrospective study was to summarize the clinical characteristics and evaluate the management approaches of primary breast DLBCL in the era of rituximab.

\section{Patients and methods Patients and patient workup}

After obtaining approval from the Independent Ethics Committee of Zhejiang Cancer Hospital, the patients with newly diagnosed NHL $(n=1,281)$ treated between April 2006 
and May 2013 in our center were reviewed and the patients with primary breast DLBCL were retrospectively evaluated. Patient consent was waived by the Ethics Committee due to the retrospective nature of this study.

The pretreatment workup included a complete history and physical examination, liver and renal biochemical analysis, complete blood cell count analysis, bone marrow biopsy, and computed tomography of the chest, abdomen, and pelvis. Histopathological diagnosis was based on the World Health Organization's nomenclature, and staging classification was performed according to the Ann Arbor classification. ${ }^{11,12}$

\section{Treatment protocol}

After diagnosis of primary breast DLBCL with a core needle or surgery, chemotherapy (four to six cycles of CHOP or CHOP-like regimens, with or without intrathecal methotrexate or cytarabine) with or without radiotherapy was performed. Rituximab was recommended for patients with primary breast DLBCL. Following the month of completing chemotherapy, the involved site radiotherapy of 30-46 Gy in 15-25 fractions at 1.8-2.0 Gy per daily fraction was delivered. The efficacy of treatment was assessed according to the international workshop to standardize response criteria for NHL. ${ }^{13}$

\section{Follow-up and statistical analysis}

The last follow-up was in June 2015. The follow-up was performed by the oncologic outpatient clinic by contacting the patients or their relatives by telephone. SPSS 17.0 (SPSS Inc., Chicago, IL, USA) was used for statistical analysis. The Kaplan-Meier method was used to calculate the OS and progression-free survival (PFS) rates. OS was measured from the date of diagnosis to the date of death or last follow-up. PFS was defined as the length of time from the date of diagnosis to first disease progression or death. Survival curves were plotted using the Kaplan-Meier method and compared using the log-rank test. Univariate analysis was performed to determine prognostic factors. Differences were considered significant for $P$-values $<0.05$, and all $P$-values were two tailed.

\section{Results}

\section{Baseline characteristics}

A total of 24 female patients were analyzed retrospectively. The baseline characteristics are listed in Table 1. For the whole group, the median age was 50 years (range 24-69 years). All patients had the disease detected with a palpable mass. The right breast was involved more frequently $(54.2 \%$ vs $33.3 \%)$, and three $(12.5 \%)$ patients had bilateral
Table I Clinical characteristics

\begin{tabular}{|c|c|c|c|}
\hline Characteristic & $\begin{array}{l}\text { Whole } \\
\text { group } \\
(\mathrm{N}=24)\end{array}$ & $\begin{array}{l}\text { With } \\
\text { rituximab } \\
(n=10)\end{array}$ & $\begin{array}{l}\text { Without } \\
\text { rituximab } \\
(n=\mid 4)\end{array}$ \\
\hline \multicolumn{4}{|l|}{ Sex } \\
\hline Male & $0(0.0)$ & $0(0.0)$ & $0(0.0)$ \\
\hline Female & $24(100.0)$ & $10(100.0)$ & $14(100.0)$ \\
\hline \multicolumn{4}{|l|}{ Age (years) } \\
\hline Median & 50 & 46 & 52 \\
\hline Range & $24-69$ & $24-66$ & $28-69$ \\
\hline \multicolumn{4}{|c|}{ ECOG performance status at presentation } \\
\hline 0 & $12(50.0)$ & $3(30.0)$ & $9(64.3)$ \\
\hline I & $12(50.0)$ & $7(70.0)$ & $5(35.7)$ \\
\hline \multicolumn{4}{|l|}{ Laterality } \\
\hline Right & $13(54.2)$ & $6(60.0)$ & $7(50.0)$ \\
\hline Left & $8(33.3)$ & $3(30.0)$ & $5(35.7)$ \\
\hline Bilateral & $3(12.5)$ & $I(10.0)$ & $2(14.3)$ \\
\hline \multicolumn{4}{|l|}{ Tumor size $(\mathrm{cm})^{\mathrm{a}}$} \\
\hline Median & 4 & 4 & 3 \\
\hline Range & $1-10$ & $1-10$ & $1.5-10$ \\
\hline \multicolumn{4}{|c|}{ Nodal sites' involvement at diagnosis } \\
\hline None & $15(62.5)$ & $7(70.0)$ & $8(57.1)$ \\
\hline Axillary & $8(33.3)$ & $3(30.0)$ & $5(35.7)$ \\
\hline Supraclavicular + axillary & I (4.2) & $0(0.0)$ & I (7.I) \\
\hline \multicolumn{4}{|l|}{ Lactate dehydrogenase } \\
\hline Elevated & $5(20.8)$ & $2(20.0)$ & $3(2 \mid .4)$ \\
\hline Normal & $19(79.2)$ & $8(80.0)$ & II (78.6) \\
\hline \multicolumn{4}{|l|}{ B-symptoms present } \\
\hline Absent & $23(95.8)$ & $10(100.0)$ & $13(92.9)$ \\
\hline Present & I (4.2) & $0(0.0)$ & I (7.I) \\
\hline \multicolumn{4}{|l|}{ Ann Arbor stage } \\
\hline $\mathrm{IE}$ & $13(54.2)$ & $6(60.0)$ & $7(50.0)$ \\
\hline IIE & II (45.8) & $4(40.0)$ & $7(50.0)$ \\
\hline \multicolumn{4}{|l|}{ Adjusted IPI } \\
\hline 0 & $9(37.5)$ & $4(40.0)$ & $5(35.7)$ \\
\hline I & $10(4 \mid .7)$ & $4(40.0)$ & $6(42.9)$ \\
\hline 2 & $4(16.7)$ & $2(20.0)$ & $2(14.3)$ \\
\hline 3 & I (4.2) & $0(0.0)$ & I (7.I) \\
\hline
\end{tabular}

Notes: ${ }^{\mathrm{a}}$ For bilateral cases, this is the larger value of the left and right breast diameters. 'One point each for age $\geq 60$ years, stage II, increased serum lactate dehydrogenase, and an ECOG performance status $\geq 2$. Data is presented as $n(\%)$ unless otherwise stated.

Abbreviations: ECOG, Eastern Cooperative Oncology Group; IPI, International Prognostic Index.

breast involvement. Data for germinal center or nongerminal center phenotypes based on immunohistochemistry using the Hans method were available in 14 patients: germinal center B-cell in six, non-germinal center B-cell in eight, and undefined in ten.

\section{Treatment and response}

The first-line therapy administered is summarized in Table 2. Twenty-three patients $(95.8 \%)$ received chemotherapy, and four patients $(16.7 \%)$ received CNS prophylaxis, which consisted of intrathecal cytarabine $(n=1)$ or methotrexate $(n=3)$. Ten patients $(41.7 \%)$ received rituximab. Twelve patients received radiotherapy with a median dose of $36 \mathrm{~Gy}$ 
Table 2 First-line therapy

\begin{tabular}{|c|c|}
\hline Items & No of patients (\%) \\
\hline \multicolumn{2}{|l|}{ Treatment } \\
\hline Surgery alone & $\mathrm{I}(4.2)$ \\
\hline Chemotherapy alone & $2(8.3)$ \\
\hline Radiation and chemotherapy & $5(20.8)$ \\
\hline Surgery and chemotherapy & $9(37.5)$ \\
\hline Surgery, chemotherapy, and radiation & $7(29.2)$ \\
\hline \multicolumn{2}{|l|}{ Surgery $(n=17)$} \\
\hline Lumpectomy & $12(50.0)$ \\
\hline Modified mastectomy ${ }^{\mathrm{a}}$ & $5(20.8)$ \\
\hline \multicolumn{2}{|l|}{ Chemotherapy $^{\mathrm{b}}(\mathrm{n}=23)$} \\
\hline Anthracycline containing & $23(95.8)$ \\
\hline Rituximab administered & $10(4 \mid .7)$ \\
\hline \multicolumn{2}{|l|}{ Cycles of chemotherapy } \\
\hline$<4$ & I (4.2) \\
\hline $4-6$ & $20(83.3)$ \\
\hline$>6$ & $2(8.3)$ \\
\hline \multicolumn{2}{|l|}{ Radiation } \\
\hline \multicolumn{2}{|l|}{ Fields $(n=12)$} \\
\hline Initially involved breast only & $4(16.7)$ \\
\hline $\begin{array}{l}\text { Initially involved breast and } \\
\text { regional lymph nodes }\end{array}$ & $8(33.3)$ \\
\hline \multicolumn{2}{|l|}{ Radiation dose (Gy) } \\
\hline Median & 36 \\
\hline Range & $30-46$ \\
\hline
\end{tabular}

Notes: anitially misdiagnosed as carcinoma of the breast. 'Intrathecal chemotherapy, four patients.

(range 30-46 Gy). Among the 23 patients who were treated with chemotherapy, 17 (73.9\%) had a complete response, five $(21.7 \%)$ had a partial response, and one $(4.3 \%)$ had progressive disease.

The median follow-up time for all patients was 60.3 months (25.4-110 months). During follow-up, 19 patients were alive without lymphoma and five patients had died by the end of follow-up: four of them died from lymphoma and one patient died from chemotherapy-related hepatic failure. All the patients who relapsed occurred within the first 2 years. Of these, one patient had progressive disease during chemotherapy, one patient presenting with bilateral breast involvement developed left breast relapse after lumpectomy and chemotherapy, one patient developed bone marrow involvement, and one patient developed skin relapse (Table 3). No patients developed CNS relapses. The KaplanMeier estimated 1-year, 3-year, and 5-year PFS rates of all the patients was $87.5 \%, 79.2 \%$, and $79.2 \%$, respectively, and the Kaplan-Meier estimated 1-year, 3-year, 5-year OS was $91.7 \%, 78.9 \%$, and $78.9 \%$, respectively (Figure 1).

\section{Prognostic factors}

The values of various potential prognostic factors, including age, tumor size, lactate dehydrogenase, Eastern Cooperative Oncology Group performance status at presentation, Ann Arbor stage, adjusted International Prognostic Index, rituximab administered, surgery, cycles of chemotherapy $>4$, and radiation in predicting PFS and OS were evaluated. The outcomes are listed in Table 4. Although no significant difference was found in terms of PFS and OS between the patients with rituximab and the patients without rituximab, the PFS and OS of the patients with rituximab were higher (5-year PFS: $90 \%$ vs $71.4 \%, P=0.285$; 5 -year OS: $90 \%$ vs $71.4 \%, P=0.239$ ).

\section{Discussion}

Several efforts have been undertaken to evaluate the clinical characteristics and management approaches of primary breast DLBCL. Clinically, our results were consistent with the published literature; the typical presentation was a woman in her fifth or sixth decade with a solitary, unilateral, predominantly right-sided breast lump..$^{3,14-16}$

The 5-year OS rate of primary breast DLBCL reported from other centers varied from $48 \%$ to $75 \% \cdot{ }^{3,16,17}$ In our study, 5 -year OS rate of primary breast DLBCL was $78.9 \%$, which was likely to be related to the distribution of clinical characteristics and management approaches in the different reports. With regard to the patterns of relapse, $12 \%-44 \%$ relapse of primary breast DLBCL occurred in the ipsilateral or contralateral breast. ${ }^{3,4,7,14}$ Ryan et $\mathrm{al}^{3}$ reported that ipsilateral breast

Table 3 Data on the results of first-line treatment

\begin{tabular}{|c|c|c|c|c|}
\hline \multirow[t]{2}{*}{ Modality } & \multicolumn{4}{|c|}{ No of patients } \\
\hline & $\begin{array}{l}\text { Total } \\
(N=24)\end{array}$ & $\begin{array}{l}\text { Local } \\
\text { recurrence }\end{array}$ & $\begin{array}{l}\text { Distal } \\
\text { recurrence }\end{array}$ & $\begin{array}{l}\text { Disease-specific } \\
\text { mortality }\end{array}$ \\
\hline Surgery & 1 & & & \\
\hline Chemotherapy & 2 & $\mathrm{I}^{\mathrm{a}}$ & & $I^{\mathrm{a}}$ \\
\hline Radiation and chemotherapy & 5 & & & \\
\hline Surgery and chemotherapy & 9 & I & 1 & 2 \\
\hline Surgery, chemotherapy, and radiation & 7 & & 1 & I \\
\hline With rituximab & 10 & & 1 & I \\
\hline
\end{tabular}

Note: ${ }^{a}$ The patient had progressive disease during chemotherapy. 


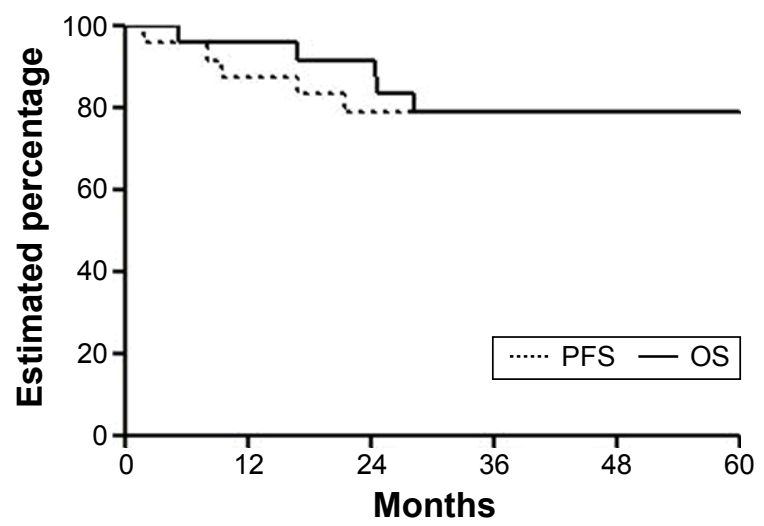

Figure I Kaplan-Meier curve showing OS and PFS of patients with primary breast DLBCL in the study.

Abbreviations: OS, overall survival; PFS, progression-free survival; DLBCL, diffuse large B-cell lymphoma.

relapse of primary breast DLBCL occurred within 2.6 years from the commencement of treatment, whereas contralateral breast relapse occurred up to 13.3 years. In the present study, three $(12.5 \%)$ patients had bilateral breast involvement on presentation and one patient who presented with bilateral

Table 4 Impact of prognostic factors on treatment results by univariate analysis

\begin{tabular}{|c|c|c|c|c|}
\hline \multirow[t]{2}{*}{ Items } & \multicolumn{2}{|c|}{ 5-year PFS } & \multicolumn{2}{|c|}{ 5-year OS } \\
\hline & $\%$ & $P$-value & $\%$ & $P$-value \\
\hline Age & & 0.153 & & 0.147 \\
\hline$\geq 50$ years & 66.7 & & 66.7 & \\
\hline$<50$ years & 91.7 & & 91.7 & \\
\hline $\begin{array}{l}\text { ECOG performance status } \\
\text { at presentation }\end{array}$ & & 0.597 & & 0.575 \\
\hline 0 & 83.3 & & 83.3 & \\
\hline 1 & 75.0 & & 75.0 & \\
\hline Tumor size $(\mathrm{cm})$ & & 0.540 & & 0.463 \\
\hline$\geq 4$ & 84.6 & & 84.6 & \\
\hline$<4$ & 72.7 & & 72.7 & \\
\hline Lactate dehydrogenase & & 0.148 & & 0.179 \\
\hline Elevated & 60.0 & & 60.0 & \\
\hline Normal & 84.2 & & 83.9 & \\
\hline Ann Arbor stage & & 0.091 & & 0.076 \\
\hline IE & 92.3 & & 91.7 & \\
\hline IIE & 63.6 & & 63.6 & \\
\hline Adjusted IPI & & 0.148 & & 0.179 \\
\hline $0-1$ & 84.2 & & 83.9 & \\
\hline $2-3$ & 60.0 & & 60.0 & \\
\hline Surgery & & 0.521 & & $0.46 I$ \\
\hline Yes & 82.4 & & 81.9 & \\
\hline No & 71.4 & & 71.4 & \\
\hline Cycles of chemotherapy $>4$ & & 0.174 & & 0.208 \\
\hline Yes & 84.2 & & 84.2 & \\
\hline No & 60.0 & & 53.3 & \\
\hline Rituximab administered & & 0.285 & & 0.239 \\
\hline Yes & 90.0 & & 90.0 & \\
\hline No & 71.4 & & 71.4 & \\
\hline Radiation & & 0.176 & & 0.183 \\
\hline Yes & 90.9 & & 90.9 & \\
\hline No & 69.2 & & 68.4 & \\
\hline
\end{tabular}

Abbreviations: PFS, progression-free survival; OS, overall survival; ECOG, Eastern Cooperative Oncology Group; IPI, International Prognostic Index. breast involvement developed left breast relapse after lumpectomy and chemotherapy with a median follow-up time of 60.3 months.

CNS relapse occurred in 5\%-23.6\% of patients with primary breast DLBCL. ${ }^{3,7,14,16,18}$ Most CNS relapses of primary breast DLBCL occurred in $<2$ years following the completion of therapy. ${ }^{16}$ However, there is currently no consensus on CNS prophylaxis for primary breast DLBCL, and the addition of rituximab to chemotherapy may decrease the rate of CNS relapse. ${ }^{19}$ In our study, four patients received CNS prophylaxis and eleven patients received rituximab and no patients developed CNS relapses after a median follow-up time of 66.8 months (25.4-110 months), This was similar to a prospective study that included 32 patients treated by rituximab and dose-dense chemotherapy and no patients developed CNS relapses after a median follow-up of 64.5 months, ${ }^{10}$ probably because of the limited patients, retrospective nature, the addition of rituximab, and intrathecal chemotherapy.

Univariate analysis indicated that none of the treatment variables, including surgery, chemotherapy, or radiotherapy, were associated with PFS or OS. There are robust data that surgical resection results in inferior local control, ${ }^{20}$ with multiple series demonstrating treatment, including mastectomy associated with higher all-cause and disease-specific mortality. ${ }^{3,14,15}$ One patient developed left breast relapse after lumpectomy and chemotherapy in our study.

To date, only randomized controlled trial of PBL showed a significantly better survival for patients who received combined chemotherapy and radiotherapy compared to either modality alone. ${ }^{8}$ Ten-year event-free survival of radiotherapy alone, chemotherapy alone, and combined chemotherapy and radiotherapy was $50 \%, 57 \%$, and $83 \%$, respectively $(P<0.01)$. Ten-year OS of radiotherapy alone, chemotherapy alone, and combined chemotherapy and radiotherapy was $50 \%, 50 \%$, and $76 \%$, respectively $(P<0.01)$. In the singlearm trial of PBL, diffuse large-cell histology, treated by rituximab and dose-dense chemotherapy, 3-year event-free survival and OS were $75 \%$ and $63 \%$, respectively. ${ }^{10} \mathrm{How}-$ ever, in this case control study of primary breast DLBCL $(n=25)$ and limited-stage nodal DLBCL $(n=75)$ treated by $\mathrm{R}-\mathrm{CHOP},{ }^{18} \mathrm{OS}$ was similar between the two groups (3-year OS rate, $82.2 \%$ vs $90.7 \%, P=0.345$ ). The PFS and OS of the patients with rituximab were higher than the patients without rituximab in the present study (5-year PFS: $90 \%$ vs $71.4 \%$, $P=0.285$; 5 -year OS: $90 \%$ vs $71.4 \%, P=0.239$ ). Rituximab is now routinely added to chemotherapy in patients with DLBCL. ${ }^{21}$ Based on our results and the previous studies, ${ }^{10,18,21}$ adding rituximab to treatment for patients with primary breast 
DLBCL is recommended. Prospective randomized trials with rituximab for primary breast DLBCL are needed.

\section{Conclusion}

Primary breast DLBCL appears to be a rare disease. Our results suggest that adding rituximab might improve survival in the patients with primary breast DLBCL. Further prospective studies are needed to evaluate the role of rituximab for primary breast DLBCL.

\section{Disclosure}

The authors report no conflicts of interest in this work.

\section{References}

1. Dobrotina AF, Zlotnikova ZB. Generalized sarcomatosis (lymphosarcomatosis) in pregnancy with unusual bilateral involvement of the breasts. Vopr Onkol. 1959;5(5):613-616.

2. Gholam D, Bibeau F, El Weshi A, Bosq J, Ribrag V. Primary breast lymphoma. Leuk Lymphoma. 2003;44(7):1173-1178.

3. Ryan G, Martinelli G, Kuper-Hommel M, et al. International Extranodal Lymphoma Study Group: primary diffuse large B-cell lymphoma of the breast: prognostic factors and outcomes of a study by the International Extranodal Lymphoma Study Group. Ann Oncol. 2008;19(2): 233-241.

4. Validire P, Capovilla M, Asselain B, et al. Primary breast non-Hodgkin's lymphoma: a large single center study of initial characteristics, natural history, and prognostic factors. Am J Hematol. 2009;84(3):133-139.

5. Wong WW, Schild SE, Halyard MY, Schomberg PJ. Primary nonHodgkin lymphoma of the breast: the Mayo Clinic experience. J Surg Oncol. 2002;80(1):19-25; discussion26.

6. Au WY, Chan AC, Chow LW, Liang R. Lymphoma of the breast in Hong Kong Chinese. Hematol Oncol. 1997;15(1):33-38.

7. Yhim HY, Kang HJ, Choi YH, et al. Clinical outcomes and prognostic factors in patients with breast diffuse large B cell lymphoma; consortium for improving survival of lymphoma (CISL) study. BMC Cancer. 2010;10:321.

8. Avilés A, Delgado S, Nambo MJ, Neri N, Murillo E, Cleto S. Primary breast lymphoma: results of a controlled clinical trial. Oncology. 2005; 69(3):256-260.
9. Cheah CY, Campbell BA, Seymour JF. Primary breast lymphoma. Cancer Treat Rev. 2014;40(8):900-908.

10. Aviles A, Castaneda C, Neri N, Cleto S, Nambo MJ. Rituximab and dose dense chemotherapy in primary breast lymphoma. Haematologica. 2007;92(8):1147-1148.

11. Harris NL, Jaffe ES, Diebold J, et al. The World Health Organization classification of hematological malignancies report of the clinical advisory committee meeting, Airlie House, Virginia, November 1997. Mod Pathol. 2000;13(2):193-207.

12. Carbone PP, Kaplan HS, Musshoff K, Smithers DW, Tubiana M. Report of the committee on Hodgkin's disease staging classification. Cancer Res. 1971;31(11):1860-1861.

13. Cheson BD, Horning JS, Coiffier B, et al. Report of an international workshop to standardize response criteria for non-Hodgkin's lymphomas. J Clin Oncol. 1999;17(4):1244-1253.

14. Jeanneret-Sozzi W, Taghian A, Epelbaum R, et al. Primary breast lymphoma: patient profile, outcome and prognostic factors. A multicentre rare cancer network study. BMC Cancer. 2008;8:86.

15. Jennings WC, Baker RS, Murray SS, et al. Primary breast lymphoma: the role of mastectomy and the importance of lymph node status. Ann Surg. 2007;245(5):784-789.

16. Hosein PJ, Maragulia JC, Salzberg MP, et al. A multicentre study of primary breast diffuse large B-cell lymphoma in the rituximab era. Br J Haematol. 2014;165(3):358-363.

17. Shao YB, Sun XF, He YN, Liu CJ, Liu H. Clinicopathological features of thirty patients with primary breast lymphoma and review of the literature. Med Oncol. 2015;32(2):448.

18. Yhim HY, Kim JS, Kang HJ, et al. Matched-pair analysis comparing the outcomes of primary breast and nodal diffuse large B cell lymphoma in patients treated with rituximab plus chemotherapy. Int J Cancer. 2012; 131(1):235-243.

19. Aviv A, Tadmor T, Polliack A. Primary diffuse large B-cell lymphoma of the breast: looking at pathogenesis, clinical issues and therapeutic options. Ann Oncol. 2013;24(9):2236-2244.

20. Radkani P, Joshi D, Paramo JC, Mesko TW. Primary breast lymphoma: 30 years of experience with diagnosis and treatment at a single medical center. JAMA Surg. 2014;149(1):91-93.

21. Habermann TM, Weller EA, Morrison VA, et al. Rituximab-CHOP versus $\mathrm{CHOP}$ alone or with maintenance rituximab in older patients with diffuse large B-cell lymphoma. J Clin Oncol. 2006;24(19): 3121-3127.
OncoTargets and Therapy

\section{Publish your work in this journal}

OncoTargets and Therapy is an international, peer-reviewed, open access journal focusing on the pathological basis of all cancers, potential targets for therapy and treatment protocols employed to improve the management of cancer patients. The journal also focuses on the impact of management programs and new therapeutic agents and protocols on

\section{Dovepress}

patient perspectives such as quality of life, adherence and satisfaction. The manuscript management system is completely online and includes a very quick and fair peer-review system, which is all easy to use. Visit http://www.dovepress.com/testimonials.php to read real quotes from published authors. 